\title{
Reflections on the Category of Surplus Value in Socialist Countries
}

\author{
Suisheng Zhao
Shaanxi Institute of International Trade \& Commerce, Department of Ideological and Political Education

Xixian new district, xi 'an, shaanxi 712046

zhaosuisheng@126.com

Keywords: Socialism; Surplus labor; Surplus value

\begin{abstract}
Surplus value is a common economic phenomena in all societies except the primitive society. It has different forms in different social relations, however. There has objectivity in the existence of surplus labor and surplus value in the production relation of socialist economy. Just like capital, surplus value has dual nature: natural property and social property .It reflects the social relation in different societies. It is positive to introduce surplus value in socialism .

The theory of surplus value is one of the two great scientific theories in Marx's life. The theory of surplus value is the cornerstone of Marx's theory of political economy. Marx's political economics has always adhered to the view that surplus value is a specific category of capitalist commodity economy and a unique economic phenomenon in capitalist society. However, the practice of China's socialist economic system reform and the reality of market economy development challenges this traditional view. With the establishment of the system of socialist market economy in our country, the traditional theories and concepts are considered to belong to categories of capitalist economic relations, such as "joint-stock system", "capital" and "land rent" etc., which have been introduced into the category of socialist economy. However, the theoretical circle is still very close to the category of "surplus value", so that the value of the surplus labor formed by laborers in the socialist economic conditions is exactly what it is called, and there is no definite category to define it. How to divide the surplus value formed by the remaining labor of socialism is also an important theoretical and practical problem to study the social market economy.
\end{abstract}

\section{The Surplus Labor is the Economic Phenomenon and Economic Category of All Social Forms Other than the Primitive Society}

The founders of marxism believed that surplus labour was not unique to capitalism. Surplus labor is a common economic phenomenon and economic category outside the primitive society.

Engels pointed out that the surplus of labor products beyond the cost of maintaining labor, and the accumulation of surplus of social production funds and reserve funds, was and is the basis of all social, political and intellectual development. In primitive society, due to the low social productivity, no surplus labor and surplus products existed. At the end of the primitive society, the metal working tools brought about rapid increase in productivity, and the human society began appearin surplus labor and produced surplus products. In slave society, slaves belong to that slave-owned society, and their Labour products are all owned by the slave-owners, and therefore the necessary Labour of the slave cannot be distinguished from the surplus labour. In feudal society, the surplus labor of peasants was mainly owned by landlords in the form of physical rent and labor rent. At the end of the feudal society, with the emergence of the capitalist production of the relationship, the rent of the money appearin, For the first time in history, surplus labour took the form of monetary value. The direct expression is "surplus value".

\section{The Objectivity of Surplus Labor and Surplus Value in Socialist Society}

In marxist theory of political economy, surplus value is regarded as the economic category of capitalism. Marx did not put forward the socialist surplus value exists, this is because according to 
the state of the development of capitalism, Marx came to this conclusion: under the laws of surplus value, the capital of continuous pursuit of surplus value, prompting the commodity economy development to the final stage of capitalism. As the basic contradiction of capitalism intensifies, the capitalist system will eventually perish. In the advanced stage of communism, will no longer there is a commodity, currency relationship, people labor will directly show the social labor, social wealth, and they will no longer exist in the form of monetary value, nature also won't have the existence of surplus value.

Although Marx believed that the advanced stage of the communist society would no longer exist in commodity and monetary relations, they were clearly certain that the first stage of communism still existed surplus labour. Since social products are allocated to individuals, the necessary social deduction should be carried out first, and the workers should be distributed according to labor distribution. this deduction, as Marx put it, refers to the surplus labor provided by laborers to the society. Therefore, in the first stage of the communist society, the working days of the laborers in the socialist stage are divided into two parts: the necessary labor and the surplus labor, namely, their own labor and the labor of the society.

Under the condition of socialist market economy, the operation of social economy must follow the market law, and the whole process of production, distribution, exchange and consumption of society must be carried out in the market by means of value and currency. Therefore, the surplus labor of socialist social workers must be manifested in the form of surplus value, and it is possible for the society to make the initial distribution and redistribution of wealth.

\section{The Name of the Value of Socialist Surplus Labor}

Since there is still surplus labor under the condition of socialist market economy, such surplus labor must exist in the form of value, and some people in the theory circle argue that the value of the remaining labor in the socialist condition should be changed to a new term. So as to call it"social value", or "net gain value", I think it is totally unnecessary.

First of all, in the subject of economics, the same category can accommodate and reflect different social and economic relations and essence. As a common phenomenon of commodity economy, surplus value depends on the social and economic relations it reflects. The surplus value is the same as that of other economics category, which reflects the connotation of different production relations in different social and economic systems. In the socialist public ownership economy, the surplus value reflects the relationship between the laborer and his labor directly and indirectly, reflecting the socialist production relationship. In the non-public economy of China, the surplus value obviously reflects the relationship between capital and employment workers.

Second, to change the name of the socialist surplus value, its starting point is to avoid the confusion of the concept, which actually brings chaos. In fact, in the various economic components of socialism, the category of surplus value also has different connotations. The surplus value in economic organization of public ownership, and the non-public economic organizations of the surplus value, surplus value of the mixed ownership economy organization, etc., they reflect the social relationship of each phase. If we give a noun to the surplus value of every type of socialist society, Isn't it more confusing to have a problem?

\section{The Significance of Introducing Surplus Value Into Socialist Society.}

The theory of surplus value and historical materialism are the two great discoveries of Marx's life, and it is these two discoveries that turn socialism from utopia to science. The recognition of the surplus value of socialism does not undermine the truth of the residual value theory, nor does it negate the marxist theory of political economy.

It is of positive significance to introduce the surplus value category into socialism. First of all, introduce category of surplus value into socialism, is conducive to deepening the understanding of socialist labor and labor theory of value, is advantageous to the socialist market economy under the conditions of surplus labor and the distribution of surplus value, help us deepen the understanding 
of the socialist market economic law and grasp. Secondly, it is necessary to further emancipate the mind by introducing the remaining value category into socialism. Thirdly, the introduction of the surplus value category into socialism is conducive to the mobilization of all positive factors. The more the surplus value created by the enterprise, the greater the contribution to the country, the people and the social development, which is conducive to encouraging enterprises to create more surplus value for the society. The introduction of the surplus value category into socialism is conducive to the mobilization of the enthusiasm of all sectors of the society. The recognition of the surplus value of socialism, the recognition of the idea of creating surplus value for society, is conducive to stimulating creativity of all sectors of society.

\section{References}

[1] Selections from Marx and Engels: volume 3 [M]. Beijing: people's publishing house, 1995. 537.

[2] Selections of marxist classics [M]. Beijing: people's publishing house.1999.173.

[3]Bai Baoli Sun Wubin. How to correctly understand the categories and names of residual labor and its formation value [J]. Thought theory education guide, 1999 (9) : 17---19.

[4] Li Tieying. Book notes on the labor theory of value [J]. Chinese social science, 2003, (1) : 25 $---40$.

[5] Yu D, Peng L. When does Inferring Reputation Probability Countervail Temptation in Cooperative Behaviors for the Prisoners' Dilemma Game? [J]. Chaos, Solitons \& Fractals, 2015, 78: 238-244. 